\title{
Association francophone internationale des directeurs d'établissements scolaires
}

Colette Paillole

\section{OpenEdition}

12 Journals

Édition électronique

URL : http://journals.openedition.org/ries/4205

DOI : $10.4000 /$ ries.4205

ISSN : 2261-4265

Éditeur

Centre international d'études pédagogiques

\section{Édition imprimée}

Date de publication : 1 décembre 1994

Pagination : 104

ISSN : 1254-4590

\section{Référence électronique}

Colette Paillole, «Association francophone internationale des directeurs d'établissements scolaires », Revue internationale d'éducation de Sèvres [En ligne], 04 | 1994, mis en ligne le 17 avril 2015, consulté le 07 janvier 2020. URL : http://journals.openedition.org/ries/4205 ; DOI : 10.4000/ries.4205

Ce document a été généré automatiquement le 7 janvier 2020.

(c) Tous droits réservés 


\title{
Association francophone internationale des directeurs d'établissements scolaires
}

\author{
Colette Paillole
}

1 L'Association francophone internationale des directeurs d'établissements scolaires (AFIDES) ${ }^{1}$ est née du besoin que ressentent les responsables d'établissements scolaires de par le monde, de coopérer et d'avoir des échanges autour du métier et de ses difficultés, dans différents systèmes, pays et cultures. L'AFIDES exprime aussi le désir de rompre l'isolement lié à l'exercice de la fonction, grâce à la création d'un espace d'amitié fondée sur le partage d'une même langue, le français.

2 Constituée à Montréal le 23 avril 1983, elle s'adresse à tous les personnels de direction d'établissements scolaires, au niveau primaire et secondaire, du secteur public et du secteur privé. Elle leur propose une identité professionnelle, une culture commune, une formation mutuelle et des liens de solidarité à travers les activités suivantes :

- la publication de la Revue des échanges, diffusée à près de 5000 exemplaires dans une cinquantaine de pays francophones du nord et du sud ;

- des colloques offrant des lieux de formation continue adaptée à la nature de leur fonction : L'école, les collectivités et le rôle du chef d'établissement... Des compétences partagées? France, novembre 1994.

Enseignements et francophonie, identités culturelles et différences. France, septembre 1994. Le chef d'établissement et les nouveaux défis de l'école. Belgique, avril 1994 ;

- enfin, un colloque international organisé tous les deux ans. Le prochain rendez-vous est prévu à Tunis, sur le thème « Diriger un établissement scolaire ; une profession ». 


\section{NOTES}

1. AFIDES France 26. rue de la Noyera, 38090 Villefontaine. Tél. : 74.96 .52 .62

\section{AUTEUR \\ COLETTE PAILLOLE}

Présidente d'AFIDES-France 